\title{
Evaluation of knowledge and attitudes of physicians in Turkey about body donation processes
}

\author{
Zeliha Kurtoğlu Olgunus (D), Çisem Yeşil Kayabaşı \\ Department of Anatomy, School of Medicine, Mersin University, Mersin, Turkey
}

\begin{abstract}
Objectives: Individuals who want to get information about body donation sometimes apply to physicians instead of Anatomy Departments in Turkey. The aim of the study was to evaluate the knowledge and attitudes of physicians who are frequently consulted by body donors.

Methods: In this descriptive study, questionnaire form which consisted of three parts and 20 questions was prepared. In the first part, demographic informations; in the second part; the physicians' answers to frequently asked body donation questions and physician responsibilities in the process; in the third part, the physicians' request for information was questioned. The survey was conducted online.

Results: Of the 238 physicians from 33 different provinces (aged between 25-68 years, 58.8\% female, $41.2 \%$ male), 62.6\% were specialist, $37.4 \%$ were non-specialized. $12.6 \%$ of them stated that at least one person applied to them for body donation. While only $52.5 \%$ of the physicians chose the Anatomy Departments to direct the donor, 35.3\% chose the Organ Donation Units. $80.3 \%$ did not know that the body of an individual who did not fill out the donation form could be donated by their relatives and $29.4 \%$ did not know that body donation does not prevent organ donation. $90.8 \%$ of the physicians stated that they needed to be informed about the laws and procedures related to cadaver donation.
\end{abstract}

Conclusion: The study reveals that physicians do not have enough information about body donation and they demand to be informed about it. The findings should be carefully evaluated as a factor that may adversely affect the decision of the body donor who cannot be properly guided by the physicians.

Keywords: attitude; body donation; cadaver supply; physician; survey

Anatomy 2021;15(2):152-162 @2021 Turkish Society of Anatomy and Clinical Anatomy (TSACA)

\section{Introduction}

Along with many technological developments that contribute to the understanding of the human body, working with cadavers in medical education and specialist training in surgical fields maintains its importance and priority all over the world. For this reason, although there are priority sub-topics that vary in different geographies, problems related to the supply of cadavers occupy an important place on the agenda of anatomists and medical educators. ${ }^{[1-24]}$ As general social and ethical values evolve in all societies over time, the historical process regarding the way of cadaver supply is also evolving from the stages of grave robbing, the use of the dead bodies of criminals or unclaimed bodies to the use of donated bodies. This evolution, which progresses at different speeds in different geographies, can be shaped by solutions accepted by the society that questions ethical values on one hand and the needs on the other, and laws and regulations develop in a way that adapts to this. ${ }^{[2,7,9,14,16,18,20,25-32]}$ Unclaimed bodies are the most common source of cadaver supply worldwide. However, the ethical problems arising from the use of

This study was as an oral presentation at the online 21st National Anatomy Congress, 27th-29th November 2020, Turkey. 
unclaimed bodies as cadavers are a disturbing factor primarily for anatomists, researchers and students, needs to be discussed and resolved. Of course, it is much more comforting for the researchers and students to know that someone has allow his body dissection while living, rather than it was approved by a medical institution. ${ }^{[28]}$ From this viewpoint, the adoption of cadaver supply through body donation is an important and efforts toward this are spreading to all continents. In the UK, one of the countries where body donation is relatively common, "The Human Tissue Act" (2004) which makes the use of unclaimed bodies illegal has been put into use. Although this practice has resulted in a decrease in cadaver supply, it is still valid. Similarly, prohibition of the use of unclaimed bodies in North American medical schools, where donor cadavers made up $80 \%$ of total cadavers, is strongly debated. ${ }^{[7,28]}$ Body donation based on the donor's informed consent, an approach that respects the donor's personal autonomy and dignity of the human body is considered as the backbone of anatomy ethics. This approach is well regulated by International Federation of Associations of Anatomists (IFAA) recommendations in 2012. ${ }^{[19]}$

In countries where the use of unclaimed bodies as cadavers is limited and body donation is insufficient, the supply of cadavers from other countries is common. In the USA, there are legal entreprises that provide human cadaver and body parts to the medical schools, medical training centers, and medical device companies. ${ }^{[3,34]}$ However, the monetary costs related to the protection, preservation and transfer of donated bodies add a commercial dimension to the issue with the profit price. Another query is whether the bequest covers the transfer of all or part of the body to other countries. Thus, transfer of these bodies between countries raises many other ethical questions for body donors, public, anatomists and students. ${ }^{[1,27]}$

Significant progress has been made in Turkey, in the legal aspect of body donation with the articles related to cadaver supply and body donation added to the Law on the Retrieval and Protection of Organs and Tissues in 1982, and the regulations made by the Ministry of Health. ${ }^{[35,36]}$ National athlete Cavit Cav, who donated his body in the same year and still continues to contribute to medical education, is one of the first examples of body donation in Turkey. ${ }^{[37]}$ Following the actions initiated by Turkish Society of Anatomy and Clinical Anatomy (TSACA) in 2012, it is observed that awareness of body donation in the society has increased slowly, and this awareness has improved the use of donated cadavers in medical faculties. ${ }^{[2,38,39]}$ The fact that the efforts to create awareness about body donation in the Turkish society turn into positive results very slowly, is similar to the processes in the other countries of the world. ${ }^{[1,12,15,1,7,20,32,40-42]}$ And, body donation is still far from fully meeting the need for cadavers in the faculties.

Although it is uncertain which factors are most responsible for the low rates of body donation in many societies, lack of awareness, religious uncertainties, distrust of medicine, hostility to new ideas and misinformation are held responsible. ${ }^{[26]}$ Turkey is considered to be one of the countries where religious and cultural characteristics negatively affect donation and the concept of voluntary donation has not yet been established. ${ }^{[3,39]}$ On the other hand, there is a strong belief that the religion factor may not be as determinant as it seems in the multi-factor body donation decision and that these difficulties can be overcome by organizing well-informed and culturally sensitive body donation programs. ${ }^{[21]}$ Israel, India, China, New Zealand and South Africa are cited as promising examples for other societies for their success in overcoming the challenges of religious, cultural and traditional beliefs through their efforts to raise awareness of the public and members of Anatomy about body donation. ${ }^{[7,12,15,17,43]}$ In Turkey, TSACA is gradually enhancing the attitudes about body donation by introducing the ways of communication for donor applications and bringing the supportive statements of competent clergy to the public, especially in the events held during "Body Donation Awareness Week" ${ }^{[20,44}$

On all continents, the accepted and encouraged option for anatomy training with cadaver is local donated bodies instead of unclaimed bodies or bodies obtained from abroad with certain monetary costs. The information obtained from body donors has an important place in determining the steps that can be taken to reach the sufficient level of body donation. There are many suggestions in the literature based on the results of the survey studies that focus on determining the sociodemographic characteristics, preferences and opinions of the donors. $^{[2,8,11,12,16,40,42,43,45-47]}$ One of the most emphasized issues is the correct and effective use of society's information resources. Resources for the body donation are generally listed as TV, social media, word of mouth from relatives, friends or other donors, and health professionals..$^{[8,1,18,25,26,43,48-50]}$ In a survey conducted in New Zealand in 2010, it was reported that the primary source of information for $13 \%$ of the population was family physicians. ${ }^{[8]}$ Anatomists in Turkey carry out studies to raise the awareness, such as radio and television programs about body donation, sharing the ceremonies of "thanks to cadaver" news on the internet, publishing on institutional websites the informative documents, etc. ${ }^{[2,39]}$ 
Reliability of the sources from which donors get information about the donation process can be a factor that will facilitate the fulfillment of the bequest. In our face-to-face interviews with body donors who applied to Mersin University Department of Anatomy, it was noted that some of the donors who applied to the family physician or any physician in the hospital claimed that the physicians were inadequate in directing them to the right address for donations and answering their questions. Some of them even stated that they "considered giving up donation" due to their problems in finding a respondent. While the number of cadavers in medical faculties is so insufficient, the fact that a person who decide to donate their bodies has difficulty in reaching the relevant units despite applying to physicians reveals that it is necessary to question how reliable the physicians are as a source of information in the body donation process. Although there are studies in the literature that evaluate whether anatomists, medical students and physicians want to donate their bodies, ${ }^{[6,8,10,13,21,23,32,38,46,51-54]}$ studies that question the attitudes of physicians who may face the body donor's questions are very limited in number and scope.

In this study, in order to reach the data that will contribute to the strategies that will improve the "DonorPhysician-Anatomist" communication bridges in Turkey, it was aimed to reveal whether the knowledge of physicians about body donation procedures and their attitude towards directing the donor to the relevant units contain any weaknesses.

\section{Materials and Methods}

This descriptive survey study consisted of 3 parts and 20 questions. The population of the study consisted of all physicians working in Turkey (as reported by the Ministry of Health, the total number of physicians is 164,594 in 2020). ${ }^{[5]}$ The first part of the questionnaire was about demographic information such as age, gender, professional working time, field of work. In the second part, there were items that question the frequency of encountering the body donors, the responses given by the physicians to some frequently asked questions by the donors, the donation form and the awareness of the physicians about their role in the donation process. Third part of the form included whether the physicians have a request to be informed about the body donation process and their preferences regarding the method of being informed. An English translation of the whole questionnaire form can be found in Appendix 1.

The online questionnaire was sent via the electronic communication addresses of the members of medical professional associations and graduates of some medical faculties in their social media groups. Those who did not work as a physician in Turkey and those work in the anatomy department were excluded. The number of physicians who voluntarily answered the questionnaire was 238 . For this study, error margin was calculated as $5.5 \%$ at the $90 \%$ significance level of the sample size. Descriptive statistics were shown in tables as numbers (n) and percentages. Pearson's chi-square test was used to compare the groups. Statistical significance level was determined as $\mathrm{p}<0.05$.

\section{Results}

Of the 238 physicians who participated in the survey from 33 different provinces of Turkey, $41.2 \%$ were male and $58.8 \%$ were female. The distribution of participants according to the geographical regions of Turkey was as follows: 86 physicians from the Mediterranean, 68 physicians from the Central Anatolia, 31 physicians from the Marmara, 25 physicians from the Eastern/Southeast Anatolia, 15 physicians from the Black Sea, and 13 physicians from the Aegean regions.

The age range of physicians was 25-68 years (mean $\pm \mathrm{SD}=37.89 \pm 10.44$ ). The distribution according to the working period in the profession was as follows: $4.2 \%$ : $0-1$ year; $28.2 \%$ : $1-5$ years; $21.4 \%$ : $6-10$ years; $16.8 \%$ : 11-20 years; $29.4 \%$ : more than 20 years. To simplify; $53.8 \%$ of the surveyed physicians have worked for 10 years or less, and $46.2 \%$ for more than 10 years.

Distribution rates by career groups were determined as; non-specialized physicians (non-specialist family physicians/general practitioners/occupational physicians) 37\%, physicians who have completed their specialization in a particular specialty (specialist physicians/sub-branch specialist/lecturers) $37 \%$, physicians currently receiving specialty training (resident physicians/research assistants) $26 \%$. Distribution of specialists and residents $(n=150)$ by branches were; internal medicine: $64.2 \%$; surgical sciences $24.5 \%$, basic medical sciences $11.3 \%$.

To the question "Did you work with cadavers during your medical education or after graduation?", $86.6 \%$ of the physicians answered "yes", while $13.4 \%$ answered "no".

To the question "Have you examined any body donation (or cadaver donation) form before?", $91.2 \%$ of the respondents answered "no", and only $8.8 \%$ answered "yes" (Table 1).

To the question "Did you know that a week of October is "body donation awareness week in Turkey?", $86.1 \%$ of the participants answered "no" and $13.9 \%$ answered "yes".

While $12.6 \%(n=30)$ of the physicians stated that there were people who applied to them for body donation, 


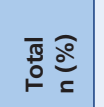
告

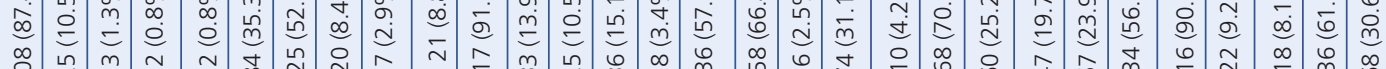

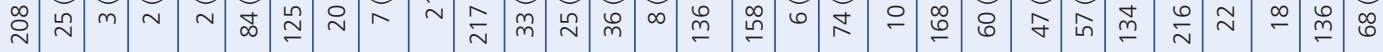

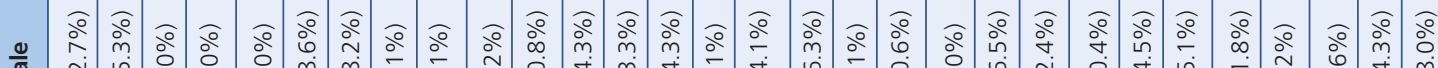

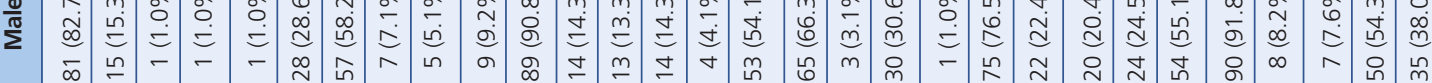

。 है

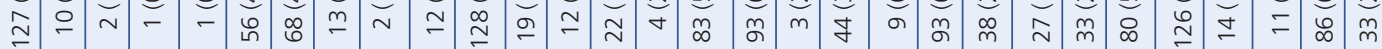

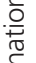

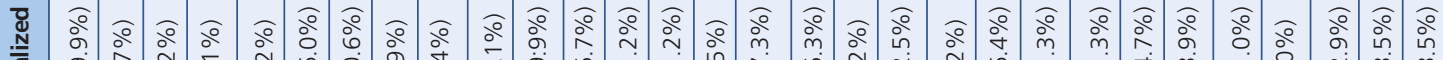

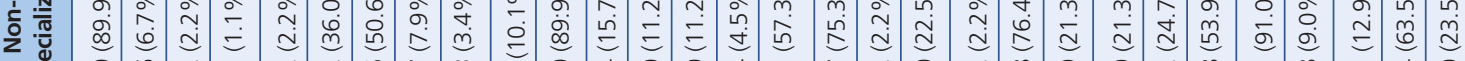

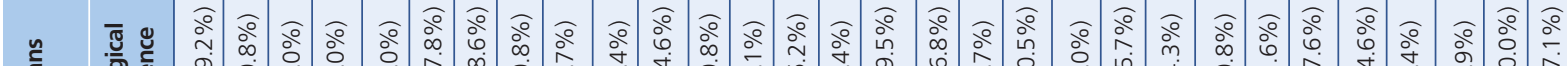

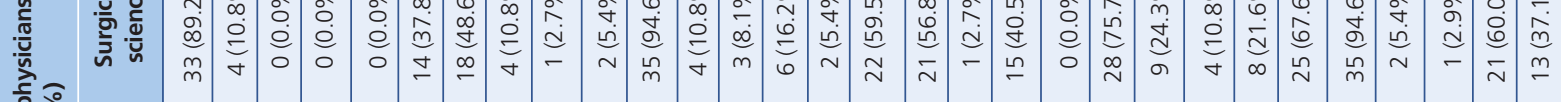

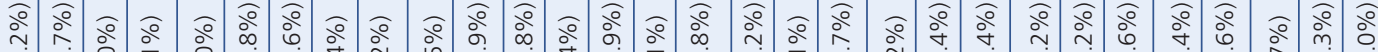

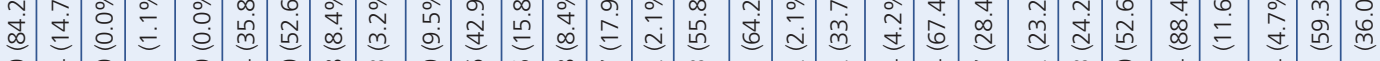

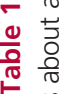

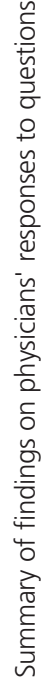

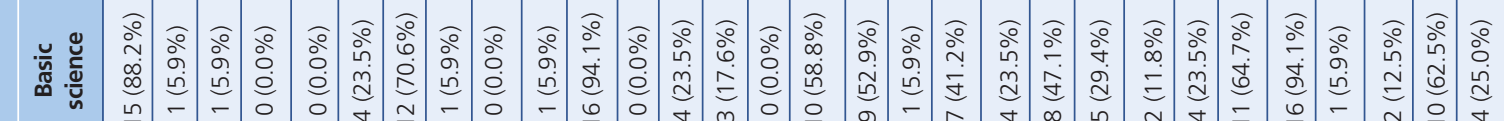
$\frac{0}{5}$

$\frac{\partial}{\stackrel{0}{\varrho}}$

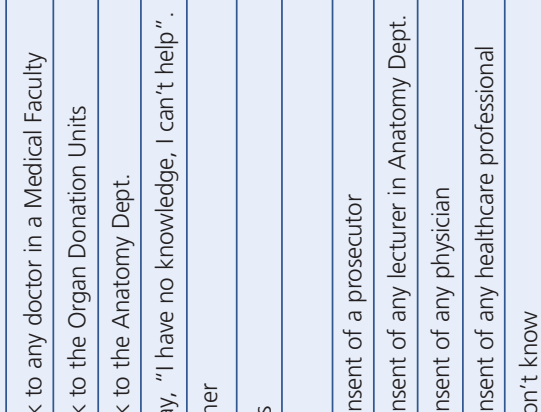

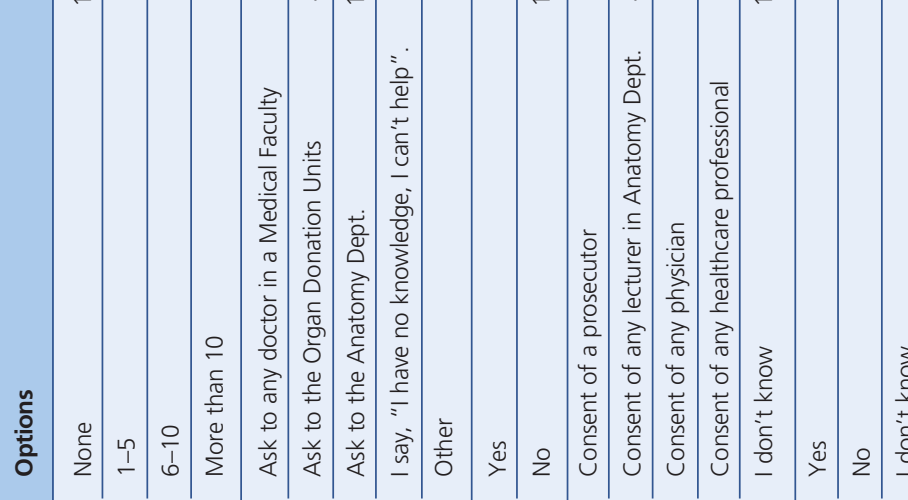

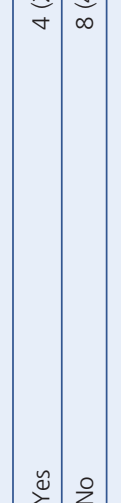

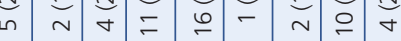

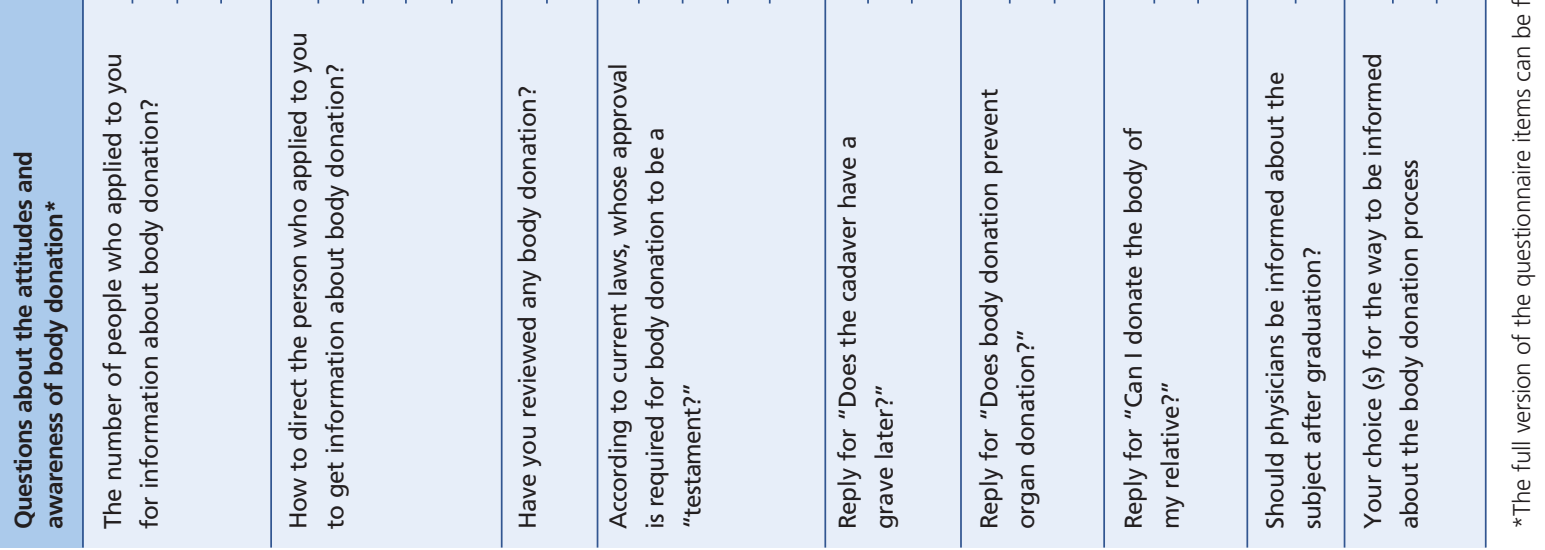


$87.4 \%$ of them stated that they did not encounter an application for body donation. $15.8 \%$ of physicians were in internal medicine, $10.8 \%$ were in surgical sciences, $11.8 \%$ were in basic medical sciences and $10.1 \%$ of non-specialist physicians stated that they encountered body donation applications (Table 1). There was no statistically significant difference between career groups in terms of encountering body donation application ( $\mathrm{p}>0.05)$.

A calculation was planned to roughly compare the estimated number of donors reaching the doctors with the number of donors reaching the anatomy department. For this, Mersin was chosen as an example due to the high participation of the questionnaire $(n=62)$ and the availability of body donation application records to the Anatomy Department in this province. Total number of physicians in Mersin was found to be 1764 on the official website of the governorship. ${ }^{[5]}$

Thirteen of the 62 people reported that they had received information requests about body donation (8 physicians had experience between between 1 and 5 years; 3 physicians between 6 and 10 years; and 2 physicians more than 11 years). With the formula below, these numbers were proportioned to the total number of physicians, taking into account the smallest number of each group:

\section{Estimated number of body donors reaching physicians in Mersin =}

$[(T M \times R R 1 / R M) \times L R 1]+[(T M \times R R 2 / R M) \times L R 2]+$ $[(T M \times R R 3 / R M) \times L R 3]$

$[(1764 \times 8 / 62) \times 1]+[1764 \times 3 / 62) \times 6]+$ $[1764 \times 2 / 62) \times 11]=1366$

TM: Total number of physicians in Mersin; RM: Total number of respondents from Mersin to the survey; RR: Number of respondents who received applications as much as in the range of the group; LR: Lower limit of the group range.

When the body donation applications were evaluated according to the working time of the physicians, it was found that $12.5 \%(16 / 128)$ of physicians working for less than 10 years and $12.7 \%(14 / 110)$ of those who worked for 10 years or more met at least one body donors.

The rate of female physicians whose information was consulted for body donation $(9.3 \%, 13 / 140$ female physicians) was found to be significantly lower than the rate of male physicians (18.4\%, 18/98 physicians) ( $\mathrm{p}=0.04)$.

For the question "How would you approach the person who applied to you to get information about body donation?", $52.5 \%$ of the physicians chose to direct the donor to the anatomy department of medical faculty, $35.3 \%$ chose to direct him/her to organ donation units (of the medical faculties, or of the community health center, or of the district health directorate). The rate of those who stated that they did not have knowledge about the subject and that they would not be able to help is $8.4 \%$ (Table 1).

To the question "Who do you think is the person who can approve the donation form by signing it it in the presence of two witnesses, according to the current laws and regulations?", $57.1 \%$ of the physicians answered "I don't know". The rate of physicians who stated that any physician could approve this form was only $15.1 \%$ (Table 1).

For the question, "Does a donated cadaver have a grave after his contributions to medical education?" $66.4 \%$ of the physicians answered "yes", while $31.1 \%$ answered "no" and $2.5 \%$ answered "I don't know".

For the question, "Does body donation prevent organ donation?" $70.6 \%$ of the physicians answered "no", $25.2 \%$ answered "I don't know" and 4.2\% answered "yes".

For the question, "My relative passed away. He did not fill out a body donation form while he was alive, but he said he wanted to be a cadaver. Can we donate his body as a cadaver?", only $19.7 \%$ answered "yes", while $23.9 \%$ answered "no" and 56.3\% answered "I don't know" (Table 1).

To the question "Did you take any courses or training on the laws and procedures related to body donation during your medical education?", only $11.8 \%$ (28 physicians) answered "yes", while $88.2 \%$ (210 physicians) answered "no".

To the question "Do you think that physicians should be informed about the laws and procedures regarding cadaver donation after graduation?", it was remarkable that the "yes" answer was $90.8 \%$ (216 physicians) (Table 1). There was no statistically significant difference between the physicians who had worked with cadavers before and those who had never worked with cadavers in terms of the answers given to this question ( $p>0.05)$. More than one option was allowed to be selected in the preferences regarding the method of informing, and 222 physicians responded. The responses were summarized in three groups: Those who selected at least one of the two options, which included only face-to-face information requests were determined as the first group, and the rate was $8.1 \%$. Those who marked at least one of the three options, which included only the requests to be informed by printed/electronic document, were determined as the second group, and the preference rate is $61.3 \%$. In the third group, there were those who ticked at least one of the options in both the first and second groups, and the rate was $30.6 \%$. Pearson's chi-square test was used to evaluate whether there were differences between career groups (internal, 
surgical, basic sciences, non-specialized groups) and genders in terms of these three knowledge preferences. There was no significant difference in terms of career groups and gender $(\mathrm{p}>0.05)$.

\section{Discussion}

Anatomy departments of Turkey are independent from each other in keeping records related to body donation, and there is no record system in which annual total donor applications to all anatomy departments can be tracked. For this reason, the records of our own institution, which is the only Anatomy department in Mersin, were used in the estimated donor calculation of the study. The estimated number of body donors reaching physicians in Mersin (1366) is considerably higher than the number of people who applied to the Anatomy Department of Mersin University (92 donors) (even if it is possible that the same person may have gone to more than one physician). The findings suggest that the donor potential in Turkey may also be higher than those registered in anatomy departments, and there is a need to facilitate donors' access to anatomists.

According to a study conducted in $2004,78.3 \%$ of anatomists recommend increasing body donation as a solution for supplying cadavers, while only $51.8 \%$ believe that donation can be a long-term solution. ${ }^{[38}$ However, it is a fact that efforts to inform the people about body donation and to improve body donation procedures and legislation began to yield positive results in the following years. ${ }^{[20]}$ TSACA declared the last week of October as the "National Anatomy Week" (Body donation awareness week) in 2012, and then this week is evaluated with various activities every year, trying to reach the public directly or through the press. ${ }^{[39,44]}$ In general, it is expected that the probability of a physician encountering any case increases with the duration of the profession. However, the results of our study show that the rate of encountering a body donor is similar between physicians who have worked for less than 10 years $(12.5 \%)$ and those who have worked for more than 10 years $(12.7 \%)$. This may be related to the fact that body donation has been questioned more and more in the last decade. In addition, it is necessary to believe in the power of informing the society instead of despairing in the face of difficult to overcome features such as psychological, cultural and religious factors that are thought to have negative effects on body donation. Our results suggest that in addition to awareness raising and procedural improvement actions, solutions to facilitate access to anatomists by individuals who have decided on body donation should be addressed. In this case, it may be of critical importance that the physicians, whom donors choose to contact first, can answer questions about the subject correctly or at least direct the donor to the right units, facilitating the completion of the donation process. It seems that anatomists are responsible for improving the knowledge resources and awareness of physicians on this subject.

Research questioning whether a physician is properly guiding body donors and answering donation-related questions is very limited. One of the most curious questions is whether the donated bodies will have a grave. Although the issue of what will happen to the corpse after the completion of the will varies according to the cultural characteristics of the countries, it is important to consider the sensitivities of the relatives. In some countries when the donated body is no longer used by anatomy institutes, it is not returned to family and friends, but is incinerated..$^{[46]}$ In the Netherlands, in recent years, considering that mourners need a symbolic resting place for their loved ones, it is stated that this practice has been accompanied by the "Body Donor Monument" built for the donor, and this practice has attracted great interest from the public. ${ }^{[57]}$ Relevant acts and regulations in Turkey indicate that the cadaver is buried when the education and research activities are completed. ${ }^{[20,35,36,39]}$ In practice, taking into account the demands of the donor and their relatives, the expectation that the donor will eventually have a grave is met, provided that he/she is buried at the end of 3-5 years. This practice, which is observed to contribute to the positive approach of donor's relatives to the bequest, is emphasized especially in public information activities. ${ }^{[39]}$ However, in this survey, a considerable amount of physicians stated that the donor body would not have a grave, or that they did not know the answer (33.6\%).

The literature emphasizes the importance of encouraging donors to discuss donation requests with relatives before death. ${ }^{[2,8,14,19,43,49]}$ There are two different aspects of the reflection of the "body donation-informed relative" relationship on the donation process. On one hand, families may negatively affect the donor's decisions on body donation, on the other hand, the presence of a family member who has donated body before increases the probability of a person to decide on body donation. ${ }^{[8,46,49]}$ The "Uniform Anatomical Gift Act (UAGA)", updated in 1987 in the USA, designated the human body as a property and allowed the fulfillment of the bequest in court even if close relatives of a donor object to the donation after death. ${ }^{[9]}$ The acts and regulations in Turkey are in favor of donation bequest and anatomist. However, in practice, even if the donor has fulfilled the bequest in accordance with the acts, if the first-degree relatives state that they are adverse- 
ly affected, the body is delivered back to the family. ${ }^{[39]}$ While filling out the body donation form in the anatomy departments, the donor is encouraged to inform the firstdegree relatives about the bequest, although it may adversely affect the donor's decision. Expanding the information authority to physicians, which can be easily reached by a wider segment of the society, including donors' relatives, may contribute to the elimination of possible negative emotional reactions.

Another question frequently asked by donors is "Does organ donation prevent body donation, and body donation prevent organ donation?" In Netherlands, where $0.1 \%$ of the population donates bodies, the bodies of people who donate their organs are not accepted by most anatomy institutes. ${ }^{[4]]}$ There is no restriction in both respects in Turkey and the physician who informs the donors is expected to explain that body donation does not prevent organ donation and organ donation does not prevent body donation. However, in our survey, $29.4 \%$ of the physicians did not mark the answer that supports the common practice.

The third one is the following question that can be directed to physicians from the relatives of any funeral: "Can I donate the body of my relative who did not have a bequest?" According to Act No. 2238, even if he/she did not make a bequest while he was alive, the relatives of the deceased can donate his/her body as a cadaver unless there is a will to the contrary. ${ }^{[2,35]} 80.2 \%$ of the physicians could not give the expected answer to this question. The fact that a considerable number of physicians could not give appropriate answers to these three questions, which may affect the decision of the body donors and their relatives, is an issue that needs to be handled carefully.

It is remarkable that only half of the physicians (52.5\%) chose to refer the body donor to the Anatomy departments and 35.3\% preferred to Organ Donation Units instead of Anatomy. However, in Turkey, as in some other countries, the body donation process is still managed only by the anatomy departments of medical faculties, and is completed with a form signed here ${ }^{[20,44,46,58]}$ Body donation procedures (informing about body donation, filling out a body donation form) are not officially within the scope of the organ donation units. These results indicate that the organ donation units of all health institutions (medical faculties, community health centers, district health directorate organ donation units, etc.) should be targeted primarily in the actions to be planned for body donation awareness for healthcare professionals.

In the Act no 2238 on organ tissue harvesting, preservation and transplantation (including also body dona- tion), Article of 6 stated that the written report signed by the donor clearly and consciously must be approved in the presence of at least two witnesses and by a "physician". ${ }^{[3,39]}$ The regulation numbered 17727 of the Health Ministry on scientific research on human body is also attributed to this act. ${ }^{[36]}$ Body donation forms created by TSACA were also prepared and used in accordance with this law and regulation. ${ }^{[58]}$ In practice, these forms are filled only under the supervision of by faculty members in anatomy departments, but this law also indicates that physicians have the authority to approve the body donation report. ${ }^{[39]}$ In this study, when physicians were asked who is the authorized person to approve the body donation form; while $57.1 \%$ of the physicians gave the answer "I don't know", the rate of those who stated that the physician would approve was only $15.1 \%$. Moreover, the rate of physicians who prefer the anatomy department option was only $10.5 \%$. Only $8.8 \%$ of the participants stated that they examined a body donation form. It is clear that physicians in Turkey, most of whom have worked on cadavers before, do not know the legal legislation on body donation. Similarly, in India in 2011, it is reported that $8 \%$ of medical professionals are unaware of the concept body donation, and most of them do not know the authority controlling body donation or the criteria for accepting donated bodies. ${ }^{[5]]}$

There are some studies in the literature that draw attention to the facts that educating physicians and medical students about body donation can play an important role in maintaining communication with potential donors. ${ }^{[7,13,21,18,23,25,51]}$ Thus physicians who are in contact with the people can be expected to participate in body donation programs, explain the importance of the bequest to those concerned, and facilitate the donation process by giving advice or answering questions. In a survey study conducted with body donors in New Zealand, 37\% of donors cited family or friends as their source of information, while only $13 \%$ cited family physicians as their primary source of information. ${ }^{[8]}$ Similarly, in the survey conducted by Conesa et al., ${ }^{[48]}$ among the information sources that affect the donation decision, health workers were in the last place after TV, press and radio, conversations with family and friends, magazines, advertisements, posters and donation campaigns. In a survey study conducted in New Zealand, South Africa and Ireland, it was reported that donors discuss donation decisions with physicians in varying degrees by country, but always less than relatives and friends. The authors suggested that donors primarily care about the comfort of the family in the decision-making process. ${ }^{[4]}$ In Turkey, where the body donors frequently reach physicians instead of anatomy, it is an important 
advantage that a physician can legally approve the body donation form. On the other hand, the fact that most of the physicians are unaware of these procedures, this advantage becomes unusable.

The results of our study showed that whether physicians worked with cadavers previously or not did not affect their demand to be informed about body donation ( $>0.05)$. On the other hand, the fact that $88.2 \%$ of the physicians who graduated from various universities did not receive any course or training on the laws and procedures related to cadaver donation during their medical education. This condition clearly explains the source of the lack of awareness reflected in the survey. Considering that there is no significant difference in the number of donors encountered between specialist subgroups and non-specialist physicians $(\mathrm{p}>0.05)$, it would be appropriate for the awareness studies to include specialist physicians and academics as well as family physicians.

Although the participation of female physicians to the survey is 1.5 times higher than that of male and there was no difference between groups in terms of information demand, the rate of donors applying to male physicians was slightly higher than those applying to female physicians. The reasons for this may be the subject of a separate sociological discussion.

The limitations of the study was that, we could not reach the total number of people who filled out the body donation form in Turkey. For this reason, it was not possible to compare the donors reaching the physicians and the donors reaching the anatomists for the whole country. Instead, we tried to interpret the records of the only anatomy department in Mersin according to the answers of the physicians participating in the study from Mersin. However, possibility of the same donor to consult more than one physician was ignored. A much more comprehensive study is needed to reveal the effect of this factor. In this survey, due to the very low number of participants in some provinces and the fact that it is common for a physician to be relocated several times during his/her professional life, an estimate of body donors by province could not be made.

\section{Conclusion}

While the lack of cadavers is accepted as an important problem affecting the quality of medical education, the supply of cadavers and body donation is quite insufficient in our country. On the other hand, the study indicates that the number of donors reaching any physicians may be higher than the number of donors filling out forms in Anatomy Departments. The results reveal that physicians in Turkey do not have sufficient knowledge about body donation and do not know how to direct the donor candidates who apply to them. This situation should be considered as a factor that may adversely affect the decision of the donor, who cannot be properly guided by a physician, and the relatives of the donor, who play an important role in the donation process. "Donor-Physician-Anatomist" communication bridges do not seem strong enough.

It was revealed in the study that $90.8 \%$ of physicians demanded to be informed about body donation. It is a very promising outcome and encourages the creation of a broad physician-focused action plan. This high rate of information requests is likely to be related to the fact that the order of this question in the questionnaire comes after items that confront the physician with critical questions from a potential donor. For this reason, in awareness-raising studies for physicians, it may be beneficial to confront physicians with possible donor questions, as well as to talk about the possibility of individuals who have decided to donate to give up donation due to misinformation. Additionaly, Organ Donation Units of all health institutions should be considered as a priority for awareness activities.

The physicians seem to almost agree that they can benefit from any printed or electronic document that includes body donation procedures, answers to the most frequently asked donor questions, and Anatomists' contact information. Considering that physicians can also contribute to body donation processes, a widespread action can be taken in line with this demand under the guidance of anatomists. Additionally, a brief course on body donation processes just before graduation in all medical faculties can also contribute to the long-term solution.

\section{Conflict of Interest}

The authors declare no conflict of interest.

\section{Author Contributions}

ZKO: project development, data analysis, manuscript writing, manuscript editing; ÇYK: data collection, data analysis

\section{Ethics Approval}

This study was approved by the Mersin University Clinical Research Ethics Committee (Approval number: 2020-677).

\section{Funding}

This research did not receive any specific grant from funding agencies in the public, commercial, or not-for-profit sectors. 


\section{References}

1. Gunderman RB, Wilson PK. Viewpoint: exploring the human interior: the roles of cadaver dissection and radiologic imaging in teaching anatomy. Acad Med 2005;80:745-9.

2. McHanwell S, Brenner E, Chirculescu ARM, Drukker J, van Mameren H, Mazzotti G, Paulsen F, Plaisant O, Caillaud MM, Laforet E, Riederer BM, Sanudo JR, Bueno-Lopez JL, Do nateOliver F, Sprumont P, Teofilovski-Parapid G, Moxham BJ. The legal and ethical framework governing body donation in Europe-A review of current practice and recommendations for good practice. European Journal of Anatomy 2008;12:1-24.

3. Sato T. Process of development of body donation in Japan. Kaibogaku Zasshi 2007;82:33-6.

4. Taylor SJ, Wilson DJ. The Human Tissue Act (2004), anatomical examination and the importance of body donation in Northern Ireland. Ulster Med J 2007;76:124-6.

5. Cornwall J, Stringer MD. The wider importance of cadavers: Educational and research diversity from a body bequest program. Anat Sci Educ 2009;2:234-7.

6. Arraez-Aybar LA, Sanchez-Montesinos I, Mirapeix RM, MonpeoCorredera B, Sanudo-Tejero JR. Relevance of human anatomy in daily clinical practice. Ann Anat 2010;192:341-8.

7. Gangata H, Ntaba P, Akol P, Louw G. The reliance on unclaimed cadavers for anatomical teaching by medical schools in Africa. Anat Sci Educ 2010;3:174-83.

8. McClea K, Stringer MD. The profile of body donors at the Otago School of Medical Sciences - has it changed? N Z Med J 2010;123:917.

9. Hulkower R. From sacrilege to privilege: the tale of body procurement for anatomical dissection in the United States. The Einstein Journal of Biology and Medicine 2011;27:23-6.

10. Anyanwu EG, Obikili EN. Dissecting the dissectors: knowledge, attitude, and practice of body bequests by Nigerian anatomists. Anat Sci Educ 2012;5:347-53.

11. Halou H, Chalkias A, Mystrioti D, Iacovidou N, Vasileiou PV, Xanthos T. Evaluation of the willingness for cadaveric donation in Greece: a population-based study. Anat Sci Educ 2013;6:48-55.

12. Rokade SA, Gaikawad AP. Body donation in India: social awareness, willingness, and associated factors. Anat Sci Educ 2012;5:83-9.

13. Green C, Bowden D, Molony D, Burke N. Felle P, Dudeney S. Attitudes of the medical profession to whole body and organ donation. Surgeon 2013;12:73-7.

14. Biasutto SN, Sharma N, Weiglein AH, Benia FM, McBride J, Bueno-Lopez JL, Kramer B, Blyth P, Barros MD, Ashiru O, Ballesteros LE, Moxham BJ, Krishnan S. Human bodies to teach anatomy: importance and procurement - experience with cadaver donation. Revistata Argentina de Anatomia Clinica 2014;6:72-86.

15. Mazyala EJ, Revocatus M, Manyama M, Msuya S, Rambau P, Kingawa E, Magelle N, Machimu Y, Joshua M, Magori CC. Human bodies bequest program: a wake-up call to Tanzanian medical schools. Advances in Anatomy 2014:940472.

16. Kramer B, Hutchinson EF. Transformation of a cadaver population: analysis of a South African cadaver program, 1921-2013. Anat Sci Educ 2015;8:445-51.

17. Zhang L, Xiao M, Gu M, Zhang Y, Jin J, Ding J. An overview of the roles and responsibilities of Chinese medical colleges in body donation programs. Anat Sci Educ 2014;7:312-20.

18. Riederer B.M. Body donations today and tomorrow: what is best practice and why? Clin Anat 2016;29:11-8.
19. Winkelmann A. Consent and consensus - ethical perspectives on obtaining bodies for anatomical dissection. Clin Anat 2016;29:70-7 .

20. Gürses AI, Coşkun O, Öztürk A. Current status of cadaver sources in Turkey and a wake-up call for Turkish anatomists. Anat Sci Educ 2017;11:155-65.

21. Galic BS, Drvendİija Z, ·trkalj G. Attitudes of medical and allied medical students from Serbia toward whole body donation. Bioscience Jornal 2016;32:1388-402.

22. Cahill DR, Leonard RJ, Weiglein AH, von Ludinghausen M. Viewpoint: unrecognized values of dissection considered. Surg Radiol Anat 2002;24:137-9.

23. Ciliberti R, Gulino M, Gazzaniga V, Gallo F, Vellone VG, De Stefano F, Santi P, Baldelli I. A survey on the knowledge and attitudes of Italian medical students toward body donation: ethical and scientific considerations. J Clin Med 2018;7:168.

24. Parthasarathy $\mathrm{P}$, Thenmozhi MS. Body donation and its relevance in anatomy learning. Drug Invention Today 2018;10:2877-80.

25. Zhang L, Wang Y, Xiao M, Han Q, Ding J. An ethical solution to the challenges in teaching anatomy with dissection in the Chinese culture. Anat Sci Educ 2008;1:56-9.

26. Chakraborty SK, Khan H, Islam S, Yousuf BMA. Body donation and its significance in anatomy learning in Bangladesh - a review. Bangladesh Journal of Anatomy 2010;8:85-8.

27. Anyanwu GE, Udemezue OO, Obikili EN. Dark age of sourcing cadavers in developing countries: a Nigerian survey. Clin Anat 2011; 24:831-6.

28. Jones DG, Whitaker MI. Anatomy's use of unclaimed bodies: reasons against continued dependence on an ethically dubious practice. Clin Anat 2012;25:246-54.

29. Riederer BM, Bolt S, Brenner E, Bueno-Lopez JL, Circulescu ARM, Davies DC, De Caro R, Gerrits PO, McHanwell S, Pais D, Paulsen F, Plaisant O, Sendemir E, Stabile I, Moxham BJ. The legal and ethical framework governing body donation in Europe - 1st update on current practice. European Journal of Anatomy 2012;16:1-21.

30. Akkin SM, Dinç G. A glimpse into the process of gaining permission for the educational dissection of human cadavers in the Ottoman Empire. Clin Anat 2014;27:964-71.

31. Ghosh SK. Human cadaveric dissection: a historical account from ancient Greece to the modern era. Anat Cell Biol 2015;48:153-69.

32. Asl JA, Nikzad H, Taherian A, Atlasi MA, Naderian H, Mousavi G, Kashani MM, Omidi A. Cultural acceptability and personal willingness of Iranian students toward cadaveric donation. Anat Sci Educ 2016;10:120-6.

33. Anteby M, Hyman M. Entrepreneurial ventures and whole-body donations: a regional perspective from the United States. Soc Sci Med 2008;66:963-9.

34. Champney TH. The business of bodies: Ethical perspectives on forprofit body donation companies. Clin Anat 2016;29:25-9.

35. T.C. Organ ve Doku Alınması, Saklanması, Aşılanması ve Nakli Hakkındaki 2238 sayılı Kanun. [Internet]. [Retrieved on April 10, 2021] Avaiable from: https://www.mevzuat.gov.tr/MevzuatMetin/ 1.5.2238.pdf.

36. T.C. Sağlık Bakanlığı, İnsan Cesedi üzerinde Bilimsel Araştırma Yapılmasına İlişkin 17727 Sayılı Yönetmelik. [Internet]. [Retrieved on April 10, 2021] Avaiable from: https://www.resmigazete.gov.tr/ arsiv/17727.pdf

37. Demirci M, Şahinoğlu S. Anatomiye adanmı? bir beden: Cavit Cav, Ankara Üniversitesi Tıp Fakültesi Anatomi Anabilim Dalında bir ilk. Ankara Üniversitesi Tip Fakültesi Mecmuası 2017;70:143-50. 
38. Şehirli US, Saka E, Sarikaya Ö. Attitudes of Turkish Anatomists toward cadaver donation. Clin Anat 2004;17:677-81.

39. Biasutto SN, Sharma NA, McBride J, Krishnan S, Vatsalaswamy P, Garud RS, Kharat VS, du Toit DF, Redwood C, Fisk W, Townsent G, Piplani ML, Romero-Reveron R, Rae G, Kachlik D, Barut C, Khayrullin RM. Part II: Human bodies to teach anatomy: importance and procurement-experience with cadaver donation. Revistata Argentina de Anatomia Clinica 2014;6:162-75.

40. Boulware LE, Ratner LE, Cooper LA, LaVeist TA, Powe NR. Whole body donation for medical science: a population-based study. Clin Anat 2004;17:570-7.

41. da Rocha AO, Tormes DA, Lehmann N, Schwab RS, Canto RT. The body donation program at the Federal University of Health Sciences of Porto Alegre: a successful experience in Brazil. Anat Sci Educ 2013;6:199-204.

42. da Rocha AO, de Campos D, Farina MA, Pacini GS, Girotto MC, Hilbig A. Using body donor demographics to assist the implementation of donation programs in Brazil. Anat Sci Educ 2017;10:47586.

43. Cornwall J, Perry GF, Louw G, Stringer MD. Who donates their body to science? an international, multicenter, prospective study. Anat Sci Educ 2012;5:208-16.

44. Turkish Society of Anatomy and Clinical Anatomy (TSACA)Report of the Board of Directors 2021. [Internet]. [Retrieved on April 10, 2021] Avaiable from: www.anatomidernegi.org.tr.

45. Lagwinski M, Bernard JC, Keyser ML, Dluzen DE. Survey of cadaveric donor application files: 1978-1993. Clin Anat 1998;11:253-62.

46. Bolt S, Eisinga R, Venbrux E, Kuks JB, Gerrits PO. Personality and motivation for body donation. Ann Anat 2011;193:112-7.

47. Asad AL, Anteby M, Garip F. Who donates their bodies to science? The combined role of gender and migration status among California whole-body donors. Soc Sci Med 2014;106:53-8.

ORCID ID:

Z. Kurtoglu Olgunus 0000-0003-0196-9975 Ç. Yeşil Kayabaşı 0000-0001-6360-6008
48. Conesa C, Zambudio AR, Ramirez P, Canteras M, Rodriguez MM, Parrilla P. Influence of different sources of information on attitude toward organ donation: a factor analysis. Transplant Proc 2004;36: $1245-8$.

49. Bolt S, Venbrux E, Eisinga R, Kuks JBM, Veening JG, Gerrits PO. Motivation for body donation to science: more than an altruistic act. Ann Anat 2010;192:70-4.

50. Cornwall J. Annual variation of body donor registrations in New Zealand. European Journal of Anatomy 2014;18:55-9.

51. Ballala K, Shetty A, Malpe SB. Knowledge, attitude, and practices regarding whole body donation among medical professionals in a hospital in India. Anat Sci Educ 2011;4:142-50.

52. Bolt S, Venbrux E, Eisinga R, Gerrits PO. Anatomists on the dissecting table? Dutch anatomical professionals' views on body donation. Clin Anat 2012;25:168-75.

53. Gürses AI, Korkmaz E, Öztürk A. Reporting detailed information and acknowledging donor-cadavers: good practice recommendation for anatomists. Anatomy 2016;10:177-81.

54. Fennel S, Jones DG. The bequest of human bodies for dissection: a case study in the Otago Medical School. N Z Med J 1992;105:472_ 4.

55. T.C. Sağlık Bakanlığı, Sağlık Hizmetleri Genel Müdürlüğünün, 54567092-610 sayıl1 Yazılı Soru Önergesi Cevab1. [Internet]. [Retrieved on September 25, 2021] Avaiable from: https://www2. tbmm.gov.tr/d27/7/7-22769sgc.pdf.

56. T.C. Mersin Valiliği resmi web sitesi. [Internet]. [Retrieved on April 10, 2021] Avaiable from: http://www.mersin.gov.tr/saglik.

57. Bolt S. Bodies does matter: gift giving and the unveiling of body donor monuments in the Netherlands. Med Anthropol Q 2012;26: 613-34.

58. Turkish Society of Anatomy and Clinical Anatomy (TSACA), Body Donation Form. [Internet]. [Retrieved on September 25, 2021] Avaiable from: http://www.anatomidernegi.org.tr/belgeler.

Correspondence to: Zeliha Kurtoğlu Olgunus, MD Department of Anatomy, School of Medicine, Mersin University, Mersin, Turkey

Phone: +905326065070

e-mail: zkurtoglu@yahoo.com

Conflict of interest statement: No conflicts declared.

This is an open access article distributed under the terms of the Creative Commons Attribution-NonCommercial-NoDerivs 4.0 Unported (CC BY-NCND4.0) Licence (http://creativecommons.org/licenses/by-nc-nd/4.0/) which permits unrestricted noncommercial use, distribution, and reproduction in any medium, provided the original work is properly cited. How to cite this article: Kurtoğlu Olgunus Z, Yeşil Kayabaşı Ç. Evaluation of knowledge and attitudes of physicians in Turkey about body donation processes. Anatomy 2021;15(2):152-162. 
Appendix 1

"Physicians and body donation" questionnaire.

\begin{tabular}{|c|c|c|c|}
\hline \multicolumn{4}{|c|}{ 1. Your name and surname (Optional): ........ } \\
\hline \multicolumn{4}{|c|}{ 2. Your age: .......... } \\
\hline \multirow{2}{*}{$\begin{array}{l}3 . \\
4 .\end{array}$} & . Indicate your gender: $\square$ Female & & \\
\hline & Write the province where you are currently working: ........ & & \\
\hline \multirow[t]{2}{*}{5.} & How many years have you been in the medical profession? & & \\
\hline & $\square$ 6-10 years & $\square 11-20$ & $\square$ More than 20 \\
\hline
\end{tabular}

6. Mark the appropriate option for your career (Mark only one option)
$\square$ Family doctor/
$\square$ Occupational physician
$\square$ Residency student
$\square$ Specialist physician
$\square$ Lecturer
$\square$ Other: .......

7. Mark the institutions you have served so far (If you have worked in more than one institution before, mark all of them)
$\square$ Family health center/Health clinic
$\square$ Community Health Center
$\square$ Occupational Medicine
$\square$ Private health center or Private hospital
$\square$ State hospital/City hospital
$\square$ University Hospital
Other: .......

8. Mark your main field of specialization (For only specialist or residency student)
$\square$ Basic sciences
$\square$ Internal sciences
$\square$ surgical sciences

9. Have you ever worked with cadavers during your medical education or after graduation?
$\square$ Yes
$\square$ No

10. During your medical education, did you receive any lectures or training on the laws and procedures regarding cadaver donation?
$\square$ Yes
$\square$ No

11. Do you know that a week of October in Turkey is "Body Donation Awareness Week"?

$\square$ Yes $\quad \square$ No

B. The section related to body donation applications answers to the donor's questions

12. Select the option that corresponds to the number of people who have applied to you to get information about body donation so far.
$\square$ None
$\square 1-5$
$\square$ 6-10
$\square$ More than 10

13. Which of the following would be your approach to the person who applied to you to get information about body donation?

$\square$ I would tell him/her ask to any doctor in the Hospital of Medical Faculty.

$\square$ I would tell him to apply to the Organ Donation Units.

$\square$ I would tell him to apply to the Anatomy Dept. of the Medical Faculty.

$\square$ I would say that I have no knowledge of the subject, and I cannot help

$\square$ Other: ........

14. Have you reviewed any body donation form before?
$\square$ Yes
$\square$ No

15. Who do you think is the person who could approve the donation form by signing it, in addition to two witnesses, according to the laws and regulations?

$\square$ Signed consent of a prosecutor

$\square$ Signed consent of any lecturer of the Anatomy Department

$\square$ Signed consent of a physician

$\square$ signed consent of any healthcare professional

$\square$ I don't know

16. What would be your answer to the question of a body donor who apply to you as: "Does a cadaver have a grave after their contribution to medical education is completed?"
$\square$ Yes
$\square$ No
$\square$ I don't know

17. If a body donor applies to you, "Does body donation prevent organ donation?" What would be your answer to the question?
$\square$ Yes
$\square$ No
$\square$ I don't know

18. What would be your answer to a person who ask you "My relative passed away. He had not filled out a body donation form, but he wanted to be a cadaver Can we donate his body as a cadaver?"
$\square$ Yes
$\square$ No
$\square$ I don't know

\section{The section related to need for information about body donation}

19. Do you think that physicians should be informed about the laws and procedures regarding cadaver donation after graduation?

$$
\square \text { Yes } \quad \square \text { No }
$$

20. (Please answer this question, if your reply to the previous question is "Yes",) Select the options you prefer for information activities about cadaver-related processes, laws and procedures related to body donation (You can tick more than one item).

$\square$ If a conference is held on the subject, I will attend.

$\square$ If interactive small group sessions or seminars are organized to inform about the subject, I will attend

$\square$ If a detailed information text on the subject is delivered to me as a printed material, I will examine it.

$\square$ If the addresses of the web pages where I can get detailed information about the subject are sent to me, I will use it.

$\square$ If the contact addresses of the people I can get information from are sent to me, I will take it into account.

Other: ......... 